\title{
The influence of power in supply chain innovation: a case study of the Dutch wheat chain
}

\author{
Hanneke Pol and Klaasjan Visscher \\ School of Management and Governance, University of Twente, P.O. Box 217, 7500 AE, Enschede, the Netherlands; \\ k.visscher@utwente.nl
}

\begin{abstract}
The purpose of this article is to clarify the relationship between the power structure of a supply chain and the possibilities to realise supply chain innovations. In an in-depth case study of the faltering start of an innovation trajectory in the Dutch wheat supply chain, we show that supply chain innovations should be in line with the interests of the powerful actors in the chain. The direct interests of the actors in the innovation are naturally relevant, but the less visible, indirect effects of the innovation on the power structure of the chain are also especially important. We show that if a chain innovation is expected to decrease the value of a resource on which the current power position of an actor in the chain is based, this actor is likely to resist it. Furthermore, an actor that derives power from the flexibility to choose among suppliers is likely to resist an innovation that requires collaboration and increased mutual commitment. This article also proposes strategies to overcome the resistance of powerful actors to such innovations.
\end{abstract}

Keywords: supply chain innovation; power; resource dependence theory; wheat supply chain

\section{Introduction}

Innovation is essential for companies wanting to gain and maintain a competitive advantage (Lukas and Ferrell, 2000; Lawson and Samson, 2001; Bessant, 2003). Whereas in the past, innovation may have been a challenge faced by individual companies, nowadays innovating is to a large extent a network activity (Håkansson, 1987; Koza and Lewin, 1998; Von Raesfeld Meijer, 1998; Soh and Roberts, 2003; Faems et al., 2005). The relationships between buyers and suppliers play an especially important role. Håkansson (1987) states: 'Through interaction with a major customer, a firm may develop a product that better fits the market needs, gain access to technical ability and application know-how, share the development costs, and reduce innovation cycle time, which in turn may lead to faster market introduction'. Much research has been conducted on the dyadic buyer-supplier relationship (Håkansson, 1982, 1987; Nooteboom, 1999; Kim, 2000; Sandhaya and Mrinalini, 2002; Knudsen, 2007), but until recently, few studies have focused on innovation in a whole supply chain made up of multiple buyer-supplier relationships. With the complexity of innovations steadily increasing, this area of study is now receiving greater attention (Omta, 2002; Stijnen et al., 2002; Batterink et al., 2006), particularly with respect to the collaboration among supply chain members that is essential for innovation (Stijnen et al., 2002).

Collaboration among chain actors in pursuit of innovation is not inevitable. Different organizations have different interests and may envision different directions for innovation. An alignment of interests is necessary to enable innovation, and a misalignment may hinder innovation, especially when this misalignment concerns powerful actors (Greenwood and Hinings, 1996). Previous studies have shown that it is important to understand the interests of separate organisations and the power they have to effectively pursue those interests (Omta, 2002, 2004). However, the relationship between power and commitment to an innovation is complex and not yet well understood. Further study is needed on the question of how power dependencies influence the chances of an innovation being realised, and which options are available to create favourable conditions for supply chain innovation. The purpose of this article is to uncover the mechanisms by which the power structure in the chain influences supply chain innovation.

To this end, we conducted an in-depth, single case study of innovation in the Dutch wheat supply chain. Forty years ago, $40 \%$ of Dutch wheat was used by the milling industry for bread production (Kauderer, 1993), while currently, only $15 \%$ is used for this purpose (Productschap Granen, Zaden en Peulvruchten, 2007). The remainder of the milled wheat is used for other purposes such as animal feed. Branch organisations, supported by the government, explored the possibilities of increasing the share of wheat that is suitable for bread production (i.e. milling-wheat), because of the higher margins thus obtainable. They identified technological innovations that could increase this share, but, although these innovations would benefit the chain partners 
and the chain as a whole, important actors are not willing to commit themselves to pursuing them. In this study, we will show how the power structure and the interests of the partners lead to this unwillingness. Obviously, the direct interests and perceived benefits of an innovation play a role. Less obvious, however, is the important role played by the potential effects of an innovation on the current power structure of the chain.

\section{Power, resources and supply chain innovation}

In the definition of Pfeffer and Salancik (1978:53-54), 'power is the capability to realize [one's] own goals, even in resistance against others, whereby that capability is based on the possibilities to enforce certain sanctions. This sanction possibility lies in the fact that organizations are interdependent on each others' resources in their functioning. Acquiring, managing and controlling resources is decisive for organisational survival, but, as a single organisation cannot acquire all its resources internally, it has to attract certain resources externally. Because resources are not divided equally among organisations, power imbalances develop between them (Casciaro and Piskorski, 2005; Hillman et al., 2009). Organisations possessing scarce resources have power over other organisations that are in need of these resources. As Emerson (1962:33) phrased it, 'power resides implicitly in the other's dependence.' Power relations can determine whether organisations can succeed in developing their own business, and whether they can influence other organisations in a desired direction.

According to Mintzberg (1983), three characteristics of resources create power. First, the resource must be of importance to another organisation; it must be essential to carry out that organisation's business or reduce important uncertainties. Second, the concentration of a resource is relevant. More power is gained when scarce resources are in the hands of just one or a few organisations working together. Third, resources provide more power when they are difficult to replace (see also Hickson et al., 1971; Pfeffer, 1981).

Power relations, based upon the unequal division of resources, develop within a supply chain (Cool and Henderson, 1998). A supply chain can be defined as a 'network of connected and interdependent organizations mutually and cooperatively working together to control, manage and improve the flow of materials and information from suppliers to end users' (Christopher, 1998:18-19). The actors in a supply chain are linked to each other because of their need for each other's materials and information. As a result, dependencies arise between them. Resources in the chain are regarded as being concentrated when they are supplied by only one, or a few actors. When scarce resources are concentrated within one actor, a monopoly exists; when they are possessed by a few, an oligopoly exists. In a monopoly or oligopoly, the suppliers of the resource have power over those who want it. They have the opportunity to steer the supply chain in the direction they desire.

For organisations, resources are not only needed to continue their current business, but also to innovate their business (Burgelman and Maidique, 1988; Prahalad and Hamel, 1990; Narayanan, 2001). Resources such as technological knowledge and skills, financial resources, R\&D infrastructure and downstream capabilities are required for successful innovation. The actors that possess these resources can control the innovation. According to Pinch and Bijker (1984), innovation processes are 'multidirectional'. Innovation involves the competition and conflict between the views of relevant actors, or groups of actors that share a particular set of understandings and meanings about an innovation. These groups will have different views about the most appropriate design of the artefact, or whether it is a desirable innovation (Latour, 1993; McLoughlin and Harris, 1997). Russell (1986), in his critique on the work of Pinch and Bijker, adds that 'an explanation of technological change must show not only what different social groups think about an artefact, but also what they are able to do about it - their differing abilities to influence the outcome of its development and adoption' (Russell, 1986:335-336). Not all actors have the power to bring about change to suit their objectives. Only those who own the resources needed for innovation can bring about change. For a successful innovation, those who possess the requisite resources therefore have a big say in the innovation process. They may steer the innovation process, but, when an innovation is not in their particular interest or even weakens their position, they may resist or block it (Pinch and Bijker, 1984; Mokyr, 1992; Greer and Ford, 2009).

Innovation processes always involve uncertainties (Dosi, 1988), caused by a lack of information and other resources (Zaltman et al., 1973; Pelz, 1985; Wolfe, 1994). Collaboration and resource sharing are means to cope with uncertainty and to spread the risk (Miles and Snow, 1992; Ibarra, 1992; Gulati, 1995; Powell et al., 1996; Bossink, 2002). Supply chain innovations mostly require collaboration (Stijnen et al., 2002). However, collaboration does not necessarily imply an equal relationship between the partners. Depending upon the resources needed for the innovation - generally capital, knowledge and skills - certain parties may be dominant (Katila et al., 2008). If a company is able to provide essential resources required for the innovation, it can play a dominant role in the innovation process. This is not automatically the company with the most power in the current supply chain: the resources needed for innovation may be different from 
the resources needed to run the current chain. However, a powerful member of the current chain is usually able to resist any proposed innovation it does not support.

Successful supply chain innovation requires sufficient resources and the support of dominant players in the chain. The interest of dominant players is not a given though. It can be influenced by others (Pfeffer, 1992; Rowley and Moldoveanu, 2003). Various strategies to gain support for innovations can be used. If a supply chain actor possesses some power, but is unable to realise an innovation without the help of others, it can use a direct influencing strategy, using the resources on which its power is based. If an actor has less power, an indirect influencing strategy can be used. Frooman (1999) has identified several indirect influencing strategies. An actor can try to influence the norms and values the environment places upon the powerful actor. It can try to influence the decision-making agenda by attracting media attention to a certain subject. And when possible, it can ally itself with others to gain power. This last strategy can be very effective, but should be applied with care. Differences in goals can lead to a negative outcome for the initiator of the alliance (Frooman, 1999).

In summary, we conceptualise the complex relationship between the power structure of a supply chain and the possibilities to realise supply chain innovation using resource dependence theory. The mutual dependence of chain actors and the power imbalances between them result in a certain power structure, which pre-structures the possibilities to realise innovations. Supply chain innovations, which require cooperation within the chain, need to be aligned with the interests of the most powerful actors in this chain, in particular when the resources of these actors are also required in the innovation process. As such, supply chain innovations tend to reinforce the power structure within the chain. Innovations that do not align with the interests of powerful chain actors are hard to develop or implement. However, direct or indirect influencing strategies might enable less powerful chain actors to increase support for their favoured innovations, and - once successful - change the power structure within the chain.

\section{Research design}

To study the relationship between power structure and supply chain innovations, and to identify strategies that parties in favour of an innovation can use to enhance the commitment of other parties, an in-depth case study of the Dutch wheat supply chain was carried out. The main data source in this study was a series of interviews with actors in the supply chain. In total, 39 interviews were carried out with 30 different interviewees. A purposive sampling strategy
(Johnson, 1990) was used to choose the interviewees. Respondents were chosen from all groups in the supply chain: plant breeders, wheat growers, collectors, milling companies, wholesalers, bakeries and supermarkets. Within these groups, respondents were selected to cover the relevant diversity in the group: wheat growers in different parts of the country, some who have and some who do not have their own storage capacity, big and small collectors, co-operatives and private traders, big and small milling companies, and traditional and industrial bakeries. In addition, informants were interviewed, from the Community Board for Arable Farming (HPA), the Commodity Board for Cereals, Seeds and Legumes (GZP), the Agricultural Economic Institute (LEI), the Dutch Bakery Centre (NBC), the Inland Shipping Office (Kantoor Binnenvaart), the Dutch Association of Meal Manufacturers (NVM) and experts in grain cultivation and rural sociology. To enhance the reliability of the data, triangulation was used in this study. Within each group, one or more individuals were interviewed. The informants were used to check the assertions of the respondents. Information was also gathered from documentation and company visits to check and complement the interviews.

Semi-structured interviews were used for data collection (Kvale, 1996). For the interviews a topic list was constructed, with questions about the relevant partners in the chain, the resources they needed and possessed, the reasons to invest - or not to invest - in increasing the production of highquality wheat in the Netherlands, the innovations needed to realise such an increase and the opportunities and potential obstacles for those innovations. In the first interviews, open questions were asked about these topics; in later interviews, questions were more specific to make comparison possible. The interviews started with factual questions. The more sensitive questions - about interests and obstacles - were posed in the final part of the interviews, when trust between the interviewers and respondents had been established.

All interviews were recorded on tape and transcribed. The transcripts were then coded (Miles and Huberman, 1994), using the theoretical framework. The control and exchange of relevant resources were identified and classified according to importance, concentration and irreplaceability, resulting in a picture of the power structure. Further, the interests, actions and opinions of actors regarding the innovations were classified by going back and forth between the data and the framework (Glaser and Strauss, 1967). A first classification was created after the analysis of nine interviews; and this classification was fine-tuned based on the results of another series of nine interviews. The resulting framework of analysis proved robust enough for all remaining interviews. To enhance reliability, the coding of the first nine interviews was checked by another researcher. 


\section{Challenges for the Dutch wheat supply chain}

Dutch agriculture is a strong sector in the country's economy. The sector is prominent worldwide and a market leader for many important agricultural products (De Bont and Van Berkum, 2004; Jacobs and Lankhuizen, 2005; Snijders et al., 2007). It is widely believed that the Dutch arable farming sector in particular could be lifted to an even higher level (De Bont and Van Berkum, 2004; Berenschot, 2004). To achieve this, innovation is required (Van der Vorst et al., 2005; Verdouw et al., 2005). In 2006, the KodA programme was set up, with the aim of stimulating innovation and strengthening the position of Dutch arable farming in the world market (Wolfert et al., 2005). KodA stands for 'Kennis op de Akker' (Knowledge on the Field). This programme has set its sights on the possibilities to enhance the Dutch wheat supply chain. High-quality wheat suitable for bread production is a product with a high added value. Currently, only $15 \%$ of the 1.2 million tons of wheat produced annually in the Netherlands is determined to be of sufficiently high quality to be considered milling-wheat (Productschap Granen, Zaden en Peulvruchten, 2007). Protein quality of the wheat is the most important quality requirement for bread production. 'When protein content of wheat is low but protein quality is high, we still want to buy the wheat', a manager of a milling company explained. Therefore, wheat growers, collectors and milling companies should concentrate on protein quality. However, this is not how the chain functions.

Wheat growers focus on quantity instead of quality. A Dutch wheat grower explains: 'I do not know how to control [the protein quality of] wheat and the price difference between milling-wheat and feed-wheat is very low. Therefore I try to get a high production quantity instead of high quality'. Moreover, weather conditions in the Netherlands are not favourable for high-quality wheat production. Under wet conditions, grains can lose their dormancy and germinate; and when this happens before harvesting, the wheat can no longer be used by milling companies (Darwinkel, 1997). This is seen as a big problem by the interviewees: 'Once every four years it goes wrong'. In comparison, in competing regions such as Eastern Germany and Northern France, this happens only once every ten years.

'The small-scale structure of the Dutch agricultural sector, compared to that of Germany and France, is also a problem', a respondent from a milling company explained. In the Netherlands, wheat production is carried out by a large number of small farms, each with its individual growing conditions, approaches to growth and choices of wheat variety. German and French collectors have less difficulty in supplying large batches of wheat of sufficient quality.
Because they are generally larger than their Dutch counterparts, they have more financial resources, which makes it easier for them to make expensive qualityenhancing investments, such as Global Positioning Systems for the precise application of nitrogen fertiliser, separation equipment and storage facilities.

Growers and collectors do not separate wheat with highprotein quality from wheat with low-protein quality. Payment by milling companies is not based on this quality, and furthermore, it is not very easy to measure protein quality. At the moment this can only be done after processing the wheat into meal and flour, or dough (De Molenaar, 2001). The tests that are available to measure protein quality earlier in the process are too complicated and time-consuming for collectors to use to separate and store wheat in silos during the busy harvest period. Only milling companies carry out these tests and thus gain information about protein quality.

In line with the Koda programme, Pol (2007) identified three innovations that could solve most problems in the primary part of the Dutch wheat supply chain: 1) a decision support system (DSS) that would support the wheat growers in their decision-making processes and enable them to produce milling-wheat; 2) a payment system based on protein quality, to ensure that wheat growers and collectors put more effort into achieving high quality, and 3) a quick measurement and separation system for protein quality. These innovations require the participation of several actors in the chain, in particular wheat growers, collectors and milling companies, and can therefore be considered supply chain innovations. These parties also have to provide most of the resources, in terms of knowledge and financial investments. The most important knowledge required is a specification of the protein quality. Milling companies know these specifications and should share them with collectors and wheat growers. Without specification, protein quality cannot be measured, managed or remunerated.

\section{Power positions in the wheat chain}

The primary part of the Dutch wheat supply chain consists of plant breeders (that develop and improve wheat varieties), wheat growers, collectors (cooperatives or grain traders that collect, store and sell wheat to industries) and milling companies (that mill wheat into meal and flour). The secondary part of the supply chain consists of traditional bakeries, industrial bakeries and supermarkets. The power of an actor was analysed based on the importance of its resources to another actor, and the concentration of these resources. As chain relationships involve a mutual exchange of resources, the importance and concentration of one 


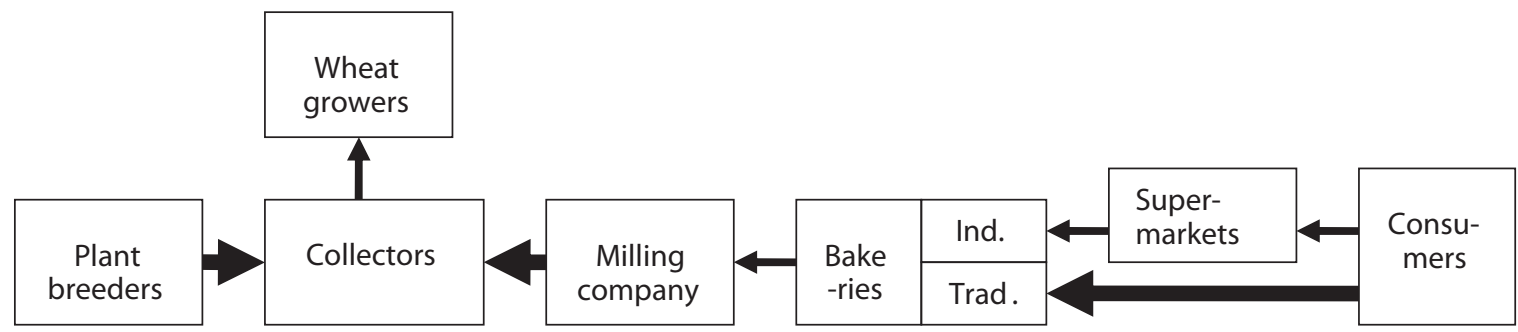

$\mathrm{A}=\mathrm{B}$ A has much more power over $\mathrm{B}$ than $\mathrm{B}$ over $\mathrm{A}$

$\mathrm{A} \longrightarrow \mathrm{B}$ A has a little more power over B than B over A

Figure 1. Power relations in the wheat supply chain.

actor's resources is regarded in respect to the importance and concentration of the other actor's resources.

The Dutch wheat supply chain is a pull market. Consumers have the greatest amount of power and other actors in the chain react to their demands. The consumers have power over the supermarkets and the traditional bakeries, which compete with each other for market share. However, the power of supermarkets in the bread market has increased in recent decades, enabling them to push aside the traditional bakeries. At present, 15\% (147,000 tonnes) of bread is sold by traditional bakeries and 78\% (763,000 tonnes) is sold by supermarkets (Voorlichtingsbureau brood, 2004). Dutch industrial bakeries and supermarkets are highly dependent on each other and thus are linked through long-term relationships. The consumer information that supermarkets can obtain, and which industrial bakeries in turn have to use, gives slightly more power to the supermarkets in these relationships.

The industrial and traditional bakeries translate the consumers' bread preferences into meal and flour specifications for the milling companies. There are only four milling companies in the Netherlands, which supply their products to many Dutch bakeries. The bakeries are well organised and thus wield considerable power despite their large number. Moreover, some industrial bakeries are quite big, and traditional, small bakeries buy wheat from a few big Dutch wholesalers. The Dutch milling companies have to compete with each other for contracts with these big customers. The bakeries' power over the milling companies is further strengthened by an overcapacity of meal and flour on the European market.

The milling companies in turn have power over collectors and control that relationship. The milling companies translate meal and flour specifications into wheat specifications. They gain extra power by being the only actors that can gain information about the protein quality of wheat, which cannot be measured until it is transformed into meal, flour and dough, by way of complicated and timeconsuming tests. Based on this information, they are able to decide whether they want to buy a certain party of wheat from the collectors, and at what price. The collectors do not have information about the protein quality of the wheat they offer. They simply have to trust their buyers. Moreover, milling companies can obtain wheat from different sources; $80 \%$ of their wheat is foreign (Productschap Granen, Zaden en Peulvruchten, 2007). This reduces the power of the Dutch collectors. In addition, foreign wheat, especially from German and French collectors, has a higher quality assurance level than Dutch wheat, which reduces the milling companies' uncertainty.

Wheat growers are dependent upon the collectors for both products (seeds, fertilization applications and crop management advice) and services. Ninety-five percent of Dutch wheat growers do not have their own storage facilities and supply their wheat to the collectors straight after the harvest. The collectors have direct contact with the processing industries and, because of this, they have a good overview of prices. In return, the collectors are dependent on wheat growers, from whom they obtain money for the sale of their products and services. In short, the collectors have more power than the wheat growers, because it is not worthwhile for the wheat growers to transport wheat over long distances. In any case, they have no time for such transportation during the busy harvest period. There are two big collectors in the Netherlands that market almost half of the total wheat produced in the country (Rabobank, 2001). The area in which these large collectors are established is extensive and there is great demand for their resources, which gives them power in the chain.

Plant breeders in turn have power over the collectors. The Dutch collectors are less important to the international plant breeders than foreign collectors. The Dutch market is a small 
one for the plant breeders, and consequently, they are not particularly interested in developing 'Dutch varieties' for specific Dutch weather and soil conditions.

Overall, it can be concluded that consumers and supermarkets are the most important actors in the chain. However, when focusing on the actors that are necessary for realising the identified supply chain innovations, the milling companies are by far the most powerful. The wheat growers are the least powerful actors in the chain. In the following, the relationship between these power positions, interests and supply chain innovations will be analysed.

\section{Power, interests and supply chain innovations}

Three different innovations to improve the Dutch wheat chain were identified: a decision support system, a payment system based on protein quality, and a quick measurement and separation system for protein quality. Although the parties in the upstream part of the chain openly acknowledge the value of these innovations, they appear unwilling or only half-heartedly prepared to invest in them. Farmers and collectors hesitate because of the limited expected returns on investment. The price difference between high-quality milling-wheat and lower-quality wheat for the animal feed industry is not very big at the moment. Investment in a decision support system, or a new measurement and separation system, seems risky to them.

The unwillingness of the milling companies is partly the result of the uncertainty regarding the expected returns. The companies could profit from the investments, because of lower transport costs and higher reliability of the delivery, but on the other hand, Dutch wheat is more expensive to produce and is delivered in smaller batches than wheat from Germany and France. However, in general the milling companies expect the balance to be in favour of these investments. Their primary reason for objecting to these innovations has to do with power. To make these innovations possible, the milling companies would have to specify and share knowledge on the protein quality needed for bread production. This knowledge is a company secret, and thus a source of power in the chain. Giving up this secret would weaken the position of the mills in relation to the collectors and farmers on the one hand, and the bakeries on the other. Such a loss of power could lead to lower margins for the milling companies. Moreover, cooperation with Dutch farmers to implement the innovations would imply a certain commitment to these farmers, and thus a relative loss of power for the mills. In the current situation, they are able to hedge and choose wheat from whatever location they want, which gives them optimal power.
We can conclude that the power structure of the chain is a main obstacle for innovation. Powerful chain actors, which control a crucial resource for the innovations, are resisting further development of the innovations because they regard the probable loss of power as more important than the potential financial gains. The less powerful actors are hesitating because of the uncertain financial returns, even though the innovations would strengthen their positions in the chain. However, even if the farmers and collectors favoured the supply chain innovations, the current power structure would hinder their development.

\section{Discussion and conclusion}

The purpose of this paper was to clarify the relationship between power and the possibilities to achieve innovations in a supply chain. The study has confirmed that power matters (Morgan and Murdoch, 2000; Omta, 2002, 2004). For successful supply chain innovations it is important that innovations are in line with the interests of the powerful actors in the chain. Without an alignment of interests, these innovations do not stand a chance (Latour, 1993).

Our study drew on resource dependence theory. This theory has a long-standing history, but has become a 'ghost in organizational discourse, a lingering presence without empirical substance' (Casciaro and Piskorski, 2005:167). In the current revival of resource dependence theory (Gulati and Sytch, 2007; Katila et al., 2008; Hillman et al., 2009), substantiating this theory in empirical research is a major ambition. This paper has contributed to this ambition by applying it in the study of supply chain innovation. In particular, our study has uncovered two mechanisms, related to power imbalances and mutual dependence, which influence the chances of realising a supply chain innovation. The first mechanism relates resources, interests and power imbalances to innovation success. The study has shown that the willingness or unwillingness to invest in innovation has to do not only with the direct interests of the actors in the chain, but also with the indirect consequences of innovations. Innovation involves an element of creative destruction (Schumpeter, 1912), and this destruction may make technological capabilities or the complementary assets of firms obsolete (Tripsas, 1997). In our study, the knowledge of protein quality specifications and the ability to measure protein quality turned out to be such an asset. Losing this resource would imply a shift in the power balance in the chain, and potentially diminished profitability for the actors losing power. Our proposition is that, if a supply chain innovation is expected to decrease the value of a resource on which the current power position of an actor in the chain is based, this actor is likely to resist it. If this actor is powerful and/or possesses necessary resources 
for the innovation, the supply chain innovation is likely to fail.

The second mechanism relates resources and mutual dependence to innovation success. The cooperation along the chain that is required to realize supply chain innovation (Stijnen et al., 2002) also leads to more commitment of the actors to each other (Schiele, 2010). In our study, the innovations would lead to a more integrated approach to information management along the chain, and increased commitment from farmers, collectors and milling companies to exchange information about wheat. This commitment reduces uncertainty for the partners, but also diminishes their flexibility (Von Raesfeld and Roos, 2008), which affects the power relations. If the ability of an actor in the chain to be flexible and to attract resources from other actors diminishes, this reduces the power position of this actor. In the case of increased mutual dependence between two actors, as would be created by the innovations discussed in this paper, the power these actors have over each other weakens. For the weaker partner, the net result may be positive, but for the stronger partner, the net result may be negative. Our proposition is that, if the cooperation required for a supply chain innovation increases the mutual dependence of actors and weakens the relative power position of an actor by reducing the flexibility to obtain resources, then this supply chain innovation is likely to meet resistance from this actor. Again, if this actor is powerful and/or possesses necessary resources for the innovation, the supply chain innovation is likely to fail.

The two mechanisms described, related to power imbalances and mutual dependence, may lead to unwillingness to cooperate in supply chain innovation. However, if less powerful actors do have an interest in a supply chain innovation, they could try to make the conditions for the innovation more favourable. These strategies for political action are important theoretical and empirical issues in the development of resource dependence theory (Hillman et al., 2009). We can identify two generic strategies. First, less powerful actors could try to give the more powerful actor a greater share in the innovation and minimise its loss of power. In our case, this could be done, for instance, by assuring the milling companies that high-quality wheat will be supplied at a reasonable price, by agreeing on confidentiality about certain parameters, and by giving the mills a leading role in quality control. Second, less powerful actors could increase their power by influencing or allying themselves with other actors (Frooman, 1999; Rowley and Moldoveanu, 2003). In our case, this could include lobbying the government, or cooperating with supermarkets and traditional bakeries to stimulate the interest of consumers in regional bread made from Dutch wheat (AKK, 2005). In the latter case, milling companies would have to give some power away to the collectors and growers in order to strengthen their position with respect to the bakeries as the sole suppliers of Dutch flour and meal. Losing power upstream would be partially compensated for by gaining power downstream.

A limitation of our study is the time frame. In the case we studied, the power strategies mentioned to foster supply chain innovation have not been implemented. At the moment, one can only speculate about the chances of success. Most cases of successful supply chain innovations concern situations in which either the powerful actors support the innovation, or in which newcomers are able to realise the innovation outside the existing chain (Christensen, 1997). Cases in which less powerful incumbents are able to overcome the vested interests of more powerful incumbents seem to be rare and atypical (see Morgan and Murdoch, 2000, for the example of organic agriculture). If this case of the Dutch wheat chain turns out to be successful, this would be an interesting subject for further study. If it does not become a success, this paper has shown the mechanisms that led to its failure.

A further limitation of this study is that it concerns a single case, within a specific chain. The results are not idiosyncratic however. The mechanisms are generic and the power structure of the wheat chain resembles several other agricultural chains, with relatively many growers or breeders, powerful consumers and supermarkets, and intermediary organisations with pivotal resources and strong positions to stimulate or resist innovation within the chain. However, other chains in agriculture and industry have different power structures. Further research should be carried out in these chains to explore which additional mechanisms and power strategies can be uncovered. This would provide a fuller and richer understanding of how power influences supply chain innovations.

\section{Acknowledgements}

We would like to thank Barend van der Meulen and Wouter Zunneberg for their valuable comments and their support during this research.

\section{References}

AKK, 2005. Report of umbrella project Knowledge development, regional production and marketing, Den Haag/Wageningen.

Batterink, M.H., Wubben, E.F.M and Omta, S.W.F., 2006. Factors explaining the innovative output of firms in the Dutch agrifood industry. Paper presented at the 7th International Conference on Management in AgriFood Chains and Networks, Ede, The Netherlands, 31 May - 2 June, 2006. 
Berenschot, 2004. SWOT Voedings- en genotsmiddelen; Resultaten van de electronic boardroomsessie van 14 april 2004 voor het Ministerie van Economische Zaken.

Bessant, J., 2003. High involvement innovation. John Wiley \& Sons, Chichester, United Kingdom.

Bossink, B.A.G., 2002. The development of co-innovation strategies: Stages and interaction patterns in interfirm innovation. $R \& D$ Management, 32(4): 311-320.

Burgelman, R.A. and Maidique, M.A., 1988. Strategic management of technology and innovation. Homewood, Illinois: Irwin.

Casciaro, T. and Piskorski M.J, 2005. Power imbalance, mutual dependence, and constraint absorption; A closer look at resource dependence theory. Administrative Science Quarterly, 50(2): 167-199.

Christensen, C.M., 1997. The innovator's dilemma. Harvard Business School Press, Boston.

Christopher, M., 1998. Logistics and supply chain management: Strategies for reducing costs and improving services. London: Pitman Publishing.

Cool, K. and Henderson, J., 1998. Power and firm profitability in supply chains; French manufacturing industry in 1993. Strategic Management Journal, 19(10): 909-926.

Darwinkel, A., 1997. Teelthandleiding wintertarwe. Lelystad: PPO.

De Bont, C.J.A.M. and Van Berkum, S., 2004. De Nederlandse Landbouw op het Europese Scorebord. Den Haag, Landbouweconomisch Instituut.

De Molenaar, 2001. Kwaliteitsconrole van baktarwe, http://www. demolenaar.nl/artikelen/show.asp?id=110, 21-08-2007.

Dosi, G., 1988. The nature of the innovative process. In: G. Dosi et al.(eds.). Technical Change and Economic Theory. London: Pinter, 221-235.

Emerson, R.M., 1962. Power-dependence relations. American Sociological Review, 1(27): 31-41.

Faems, D., Van Looy, B. and Debackere, K., 2005. Interorganizational collaboration and innovation; toward a portfolio approach. Journal of Product Innovation Management, 22: 238-250.

Frooman, J., 1999. Stakeholder influence strategies. Academy of Management Review, 24(102): 191-205.

Glaser, B.G. and A.L. Strauss, 1967), The discovery of grounded theory; Strategies for qualitative research, Aldine, Chicago.

Greenwood, R. and R. Hinings, 1996), Understanding Radical Organizational Change: Bringing Together the Old and the New Institutionalism, Academy of Management Review, 21(4): 1022-1054.

Greer, B.M. and Ford, M.W., 2009. Managing change in supply chains; A process comparison. Journal of Business Logistics. 30(2): 47-63.

Gulati, R., 1995. Social structure and alliance formation patterns; A longitudinal analysis. Administrative Science Quarterly, 40: 619-652.
Gulati, R. and Sytch, M., 2007. Dependence asymmetry and joint dependence in interorganizational relationships, Effects of embeddedness on a manufacturer's performance in procurement relationships. Administrative Science Quarterly, 52(1): 32-69.

Håkansson, H. (ed), 1982. International Marketing and Purchasing of Industrial Goods. Chicester: John Wiley and sons.

Håkansson, H. (ed), 1987. Industrial technological development: A network approach. London: Croom Helm.

Hickson, D.J., Hinings, C.R., Lee, C.A., Schneck, R.E. and Pennings, J.M., 1971. A strategic contingencies' theory of intra organizational power. Administrative Science Quarterly, 16(2): 216-229.

Hillman, A.J., Withers, M.C. and Collins, B.J., 2009. Resource dependence theory; A review. Journal of Management, 35(6): 1404-1427.

Ibarra, H., 1992. Structural alignments, individual strategies, and managerial action: Elements toward a network theory of getting things done. In: Nohria, N. and Exles, R.G. (eds), Networks and organizations: Structure, form, and action. Boston MA: Harvard Business School Press, 165-188.

Jacobs, D. and Lankhuizen, M.,, 2005. De sterke Nederlandse clusters volgens de Portermethodiek anno 2003. Groningen.

Johnson, J.C., 1990), Selecting ethnographic informants. Sage, Newbury Park.

Katila, R., Rosenberger, J.D. and Eisenhardt, K., 2008. Swimming with sharks; Technology ventures, defense mechanisms and corporate relationships. Administrative Science Quarterly, 53: 295-3320

Kauderer, I.J., 1993. Wheat classification: the link between breeder, wheat grower and processor. In From Quantity to quality: Quality Day Cereals 1993. Wageningen: Stichting Nederlands Graancentrum, 47-61.

Kim, B., 2000. Coordinating an innovation in supply chain management. European Journal of Operational Research, 123(3): 568-584.

Knudsen, M.P., 2007) The relative importance of interfirm relationships and knowledge transfer for new product development success. Journal of Product Innovation Management, 24(2): 117-138.

Koza, M. P. and Lewin, A.Y, 1998. The co-evolution of strategic alliances. Organization Science. 9(3): 255-264.

Kvale, S., 1996), Interviews; An introduction to qualitative research interviewing, Sage, Thousand Oaks.

Latour, B., 1993), La clef de Berlin et autres leçons d'un amateur de sciences, Paris: Editions la Découverte.

Lawson, B. and Samson, D., 2001. Developing innovation capability in organisations: A dynamic capabilities approach. International Journal of Innovation Management, 5(3): 377-400.

Lukas, B. and Ferrell, O.C., 2000. The effect of market orientation on product innovation. Journal of the Academy of Marketing Science, 28(2): 239-247. 
McLoughlin, I. and Harris, M., 1997. Innovation, organizational change and technology. London: International Thomson Business Press.

Miles, M.B. and A.M. Huberman, 1994. Qualitative data analysis; An expanded sourcebook, Sage, Thousand Oaks, $2^{\text {nd }}$ edition.

Miles, R.E. and Snow, C.C., 1992. Causes of failure in network organizations. California Management Review, 28(3): 62-73.

Mintzberg, H., 1983. Power in and around organizations. Englewood Cliffs, NJ: Prentice Hall.

Mokyr, J., 1992. Technological inertia in economic history. Journal of Economic History, 52(2): 325-338.

Morgan, K. and Murdoch, J., 2000), Organic vs. conventional agriculture: knowledge, power and innovation in the food chain, Geoforum, 31: 159-173.

Narayanan, V. K., 2001. Managing technology and innovation for competitive advantage. Englewood Cliffs, NJ: Prentice Hall.

Nooteboom, B., 1999. Innovation and inter-firm linkages: new implications for policy. Research policy, 28(8): 793-805.

Omta, S.W.F., 2002. Innovation in chains and networks. Journal on Chain and Network Science, 2(2): 73-80.

Omta, S.W.F., 2004. Increase the innovative potential of chains and networks. Journal on Chain and Network Science, 4(2): 75-81.

Pelz, D.C., 1985. Innovation complexity and the sequence of innovating stages. Science Communication, 6: 261-291.

Pfeffer, J., 1981. Power in organizations. Marshfield, MA: Pitman Publications.

Pfeffer, J., 1992. Management with power: Politics and influence in organizations. Boston: Harvard Business School Press.

Pfeffer, J. and Salancik, G.R., 1978. The external control of organizations: A resource dependence perspective. New York: Harper \& Row Publishers.

Pinch, T.J. and Bijker, W.E., 1984. The social construction of facts and artefacts: or How the sociology of science and the sociology of technology might benefit each other. In: Bijker, W.E., T.P. Hughes and T. Pinch (eds.) The social construction of technological systems. Cambridge: The MIT Press, 17-50.

Pol, H.J., 2007. Innovation in the Dutch wheat supply chain, MSc.thesis, University of Twente, Enschede.

Powell, W.W., Koput, K.W. and Smith-Doerr, L., 1996. Inter organizational collaboration and the locus of innovation: Networks of learning in biotechnology. Administrative Science Quarterly, 41(1): 116-145.

Prahalad, C. and Hamel, G., 1990. The core competencies of the corporation. Harvard Business Review, 68(3): 79-91.

Productschap Granen Zaden en Peulvruchten, 2007. Prijzen in de sector granen 2007/2008, http://193.173.66.231/sf/sf.cgi?7199, 01-08-2007.

Rabobank, 2001. Nederlands akkerbouwkolom: Het geheel is meer dan de som der delen. Utrecht.
Rowley, T.J. and Moldoveanu, M., 2003. When will stakeholder groups act? An interest- and identity-based model of stakeholder group mobilization. The Academy of Management Review, 28(2): 204-219.

Russell, S., 1986. The social construction of artefacts: A response to Pinch and Bijker. Social Studies of Science, 16(2): 331-346.

Sandhaya, G.D. and Mrinalini, N., 2002. Changing buyersupplier relationships: reflection of dynamism and innovation in the automotive industry in India. International Journal of Technology Management, 23: 155-172.

Schiele, H., 2010. Early supplier integration; The dual role of purchasing in new product development. R\&D Management, 40(2): 138-153.

Schumpeter, J., 1912. The theory of economic development. Oxford University Press, Oxford.

Snijders, H., Vrolijk, H. and Jacobs, D., 2007. Economische kracht van agrofood in Nederland. Groningen.

Soh, P.H. and Roberts, E.B., 2003), Networks of innovators; a longitudinal perspective. Research Policy. 32: 1569-1588.

Stijnen, D.A.J.M., Scheer, F.P., Martins, F.M.S. and De Graaff, R.P.M., 2002. Productinnovatie in agroketens: Een kwalitatief onderzoek naar ketensamenwerking als kritische succesfactor van productinnovatie en -introductie in agroketens. Wageningen: Universiteit en Research Centrum.

Tripsas, M., 1997. Unraveling the process of creative destruction; complementary assets and incumbent survival in the typesetters industry. Strategic Management Journal, 18: 119-142.

Van der Vorst, J.G.A.J., Beulens, A.J.M. and Van Beek, P., 2005. Innovations in logistics and ICT in food supply chain networks. In: Jongen, W.M.F. and M.T.G. Meulenberg (eds.) Innovation in agrifood systems: product quality and consumer acceptance. Wageningen: Wageningen Academic Publishers, 245-292.

Verdouw, C.N., Wolfert, J. and Beulens, A.J.M.,, 2005. Enhancing transformational and incremental innovation with ICT, Proceedings of the joint EFITA/WCCA 2005 conference, 25-28 July, Vila Real, Portugal.

Von Raesfeld A. and K. Roos, 2008. How should a small company interact in its business network to sustain its exchange effectiveness? Creativity and Innovation Management, 17(4): 271-280.

Von Raesfeld Meijer, A., 1998. Missing the bus; a socio-cognitive perspective on technological change. International Journal of Innovation Management. 2(2): 161-182.

Voorlichtingsbureau brood, 2004. Feiten over brood, http://www. brood.net/default.asp?pid=feiten, 04-08-2007.

Wolfe, R.A., 1994. Organizational innovation: Review, critique and suggested research directions. Journal of Management Studies, 31(3): 405-431.

Wolfert, J., H.B. Schoorlemmer, P.G.A. Paree, W. Zunneberg and J.P.C. van Hoven, 2005. Kennis op de Akker - een programmeringsstudie. 2.05.05, LEI, Den Haag.

Zaltman, G., R. Duncan and Holbek, J., 1973. Innovations and organizations. New York: Wiley. 
